\title{
Deconstructing Neo-Functionalism In The Quest For a Paradigm Shift In african Integration: Post-Neo-Functionalism and The Prognostication of The Proposed Continental Free Trade area In africa
}

\author{
Jude C. Okafor, PhD, BL Ernest Toochi Aniche, Ph.D \\ Department of Political ScienceNnamdi Azikiwe University (UNIZIK), AwkaAnambra State, Nigeria \\ Department of Political ScienceFederal University Otuoke (FUO), Bayelsa State, Nigeria
}

\begin{abstract}
Historically, integration in Africa preceded European colonialism and as well predated European integration. But in the scramble for Africa, the continent was partitioned into specific spheres of influence in the Berlin Conference (1884-1885) among the various European powers. This partitioning has continued to haunt Africa many years after colonialism, reinforcing the fragmentation of African economies. The shadow of the Conference is still with us such that after over a century of pan-Africanism and five decades of modern integration in Africa, African economies remain decimated. Yet all the hitherto existing theories of integration such as functionalism, neo-functionalism, complex interdependence, intergovermentalism, etc. are Euro-centric, western, parochial, or tailor-made for European integration, and therefore, not apt to explain the defects, failures and drawbacks of African integration. Thus, there is need to deconstruct them in the quest for paradigm shift in African integration. With the use of qualitative method and some indices from the secondary sources, and by relying on a new theory of post-neo-functionalism, a synthesis of neo-nationalism, post-nationalism and humanism, this paper concludes that the proposed Continental Free Trade Area (CFTA) would be confronted with some challenges capable of overcoming, impeding or confounding its prospects, or even pre-empting it. The study is essentially critical and prognostic.
\end{abstract}

Keywords: Continentalism, continental free trade area, regional integration, neo-functionalism, neo-neofunctionalism, post-neo-functionalism, and Africa

\section{INTRODUCTION}

Historically, integration in Africa preceded European colonialism and as well predated European integration. But in the scramble for Africa, the continent was partitioned into specific spheres of influence in the Berlin Conference (1884-1885) among the various European powers. This partitioning has continued to haunt Africa many years after colonialism, reinforcing the fragmentation of African economies. The shadow of the Conference is still with us such that after over a century of pan-Africanism and five decades of modern integration in Africa, African economies remain decimated. This explains the reason why the announcement of the proposed Continental Free Trade Area (CFTA) in Africa was received with both optimism and pessimism. The optimism concerning the prospects of the proposed CFTA, though often exaggerated, is not totally unfounded as it could help African Economic Community (AEC) strengthen intra-RECs, and inter-RECs integration by reducing the incidence of multiple memberships and proliferation of regional economic groups and subgroups, among other things.The main objective of this paper is to examine the prospects and challenges of the proposed CFTA in Africa. To achieve our purpose, we partition this paper into eight parts, namely, introduction; A historical overview of African integration or integration in Africa; a proposal for the establishment of CFTA in Africa; the architecture of the proposed CFTA in Africa; a compendium of main trade constraints in Africa today; the prospects of proposed CFTA in Africa; the challenges of the proposed CFTA in Africa; and conclusion and suggestions.

\section{A HISTORICAL OVERVIEW OF AFRICAN INTEGRATION OR INTEGRATION IN AFRICA}

Historically, integration in Africa preceded European colonialism and as well predated European integration. Chronologically, integration in Africa has undergone three important phases such as the first phase or phase one (the era of Islamisation or Arab colonialism), the second phase or phase two (the era of Diaspora pan-Africanism or traditional pan-Africanism), and the third phase or phase three (the era of modern panAfricanism). The first phase of integration in Africa started as early as $10^{\text {th }}$ century or even earlier with the gradual but steady Islamisation of the continent under Arab colonialism. From the coasts of the Mediterranean 
and the Red Seas to the coasts of the Atlantic and India Oceans or from Saharan Africa (covering the whole of North Africa) to sub-Saharan Africa, the rampaging Arabs continued the conquest and Islamization of Africa. Thus, this first phase was more in religious sphere or rather was essentially though not exclusively in religious realm. This was incidentally halt or rather curtailed by European penetration or incursion into Africa between $18^{\text {th }}$ and $19^{\text {th }}$ centuries. In the scramble for Africa, the various European powers defeated Arabs and both Islamized and yet to be Islamised African kingdoms culminating in Berlin Conference (1884-1885), and subsequent European colonialism (Coleman, 1958). The second phase of integration in Africa was era of early or traditional pan-Africanism during European colonialism in the late $18^{\text {th }}$ and early $19^{\text {th }}$ centuries. This was spearheaded or pioneered by Diaspora Africans in the continents of Americas and Europe like Henry SylvesterWilliams, Edward Wilmot Blyden, Marcus Garvey, W.E.B du Bois, Malcolm X, among others. The aims were to unite all people of African descent both those in Africa and those in Diaspora in American continents and Europe; tackle racial discrimination and segregation, racism, colonialism, imperialism, alien religion and slavery against blacks; and pursue freedom, self-determination, self-government, independence and decolonization for Africa (Coleman, 1958; Gassama, 2013). This phase two of integration in Africa, also known as black nationalism or Afrocentrism, is more in socio-cultural and political spheres.The third phase of African integration began in the $20^{\text {th }}$ century particularly in the 1960 s with the unification of various blocs (Brazzaville, Casablanca, and Monrovia blocs) culminating in the establishment of Organization of African Unity (OAU) in 1963 now African Union (AU) since 2001 and Abuja Treaty of 1991 that gave birth to African Economic Community (AEC). This was led by African leaders such as Haile Selassie, Julius Nyerere, Ahmed Sekou Toure, Kwame Nkrumah, Nnamdi Azikiwe, Muammar Gaddafi, among others. The aims were to achieve the unification of Africa and integration of the fragmented African economies through the fight against neocolonialism, Apartheid and white minority rule, especially in South Africa, Lesotho, Zimbabwe, etc.; movement for African renaissance, African revivalism, revival of African culture, philosophy, religion, arts, science, technology, ideology, common heritage, African socialism, African democracy and African welfarism; and the struggle for decolonization and independence of the remaining African territories under colonial rule like Namibia, Angola, Mozambique, etc. It also condemns dependency and stresses the need for collective selfreliance (Sherwood, 2012). Thus, the phase three of African integration is different from the two previous phases of integration in Africa in many ways. One, it emanated from Africa and represents the first attempt by Africans to integrate its territories; the phase one was imposed from outside (specifically the Arabs) while the phase two was spearheaded by Diaspora Africans. Two, as a corollary from the above or as a consequence of it, the third phase is properly referred to as African integration in this paper unlike the first and second phases that were appropriately called "integration in Africa". Three, the phase three of African integration is more in economic sphere with the target of ultimately embracing other spheres like political, security, social, etc. whereas the first and second phases were more on religious and socio-cultural cum political spheres, respectively. Four, from African historical perspective, the third phase of African integration as currently modelled after European integration, neo-functionalism and civilisation is a modern integration or neointegrationism while the first phase of integration in Africa was based on the classical integrationism of Arabian Islamic tradition or civilisation just as the second phase of integration in Africa represented the neo-classical integrationism revolving around African cultural revival and civilisation. Consequently, African integration is today targeted at regionalism or continentalism through regional integration and democratic reforms; and struggle against military rule and authoritarian regime type or agitations for multiparty democracy modelled after neo-functionalism. However, neo-functionalism and its revised version, neo-neo-functionalism, are essentially theories of European integration (Schmitter, 1970; Gehring, 1996; Mattli, 1999; Haas, 2001; Warleigh, 2006; McGowan, 2007; Laursen, 2008; Niemann and Schmitter, 2009). Therefore, these theories are not apt to explain the defects, failures and drawbacks of African integration. Most of European countries that adopted neo-functional approach to regional integration that resulted to European Union (EU) have transcended problems of national unity, de-industrialisation, national insecurity, etc. (Aniche, 2015). The explanatory value of neo-functionalism suffered a serious setback as a result of shortcomings or unpredictable trajectory of the upsurge of nationalism in the European Union such that many of its proponents and exponents began to question it (Hoffmann, 1966; Haas, 1975; Tranholm-Mikkelsen, 1991; Schmitter, 2003). Thus, there is need to deconstruct them in the quest for paradigm shift in African integration. The point is that neo-functionalism has many defects and while assuming that regional integration is a gradual process, its conception of integration as a linear process makes explanation of setbacks or shortcomings impossible (Schmitter, 1969; Haas, 1976). Another of its defects is that neo-functionalism assumes that integration of states is an integration of interdependence, and therefore, not adequate for explaining the incidence of dependence of African economies to Western economies and integration of dependence of the African states to another (Aniche, 2014).

This paper contends therefore that there is need to evolve the fourth phase of African integration anchored on neo-neo-integrationism of post-neo-functionalism or post-neo-nationalism that emphasises the initial integration on security matters through post-nationalism given the enormous security challenges confronting the continent 
with the subsequent and gradual phase of integration on economic and political spheres after many years of nation-building, national integration, and national development through neo-nationalism or a combination of political and economic nationalism; driven by the people or private sector rather than the government or the public sector through humanism. Actually, post-neo-functionalism is a hybrid of neo-nationalism, postnationalism and humanism (Aniche, 2015).

\section{A PROPOSAL FOR THE ESTABLISHMENT OF CONTINENTAL FREE TRADE AREA (CFTA) IN AFRICA}

The post-independence integration or post-colonial regionalism in Africa began with the establishment of OAU in May 1963. The other major initiatives include the adoption of the Lagos Plan of Action in 1980 and the Final Act of Lagos, and the signing of the 1991 Abuja Treaty. The Treaty entered into force on May 12, 1994. The recognized regional economic communities (RECs) which became the building eight blocks or pillars of AEC include ECOWAS, SADC, COMESA, EAC, ECCAS, CENSAD, IGAD and AMU. Since then little progress has been recorded in the process of pan-African integration (Okeke and Aniche, 2012). This is compounded with the fact that the AEC Roadmap or Treaty Framework did not originally provide for a CFTA. However, the AU Summit decision to establish the CFTA was to remedy this lacuna or missing link in the Abuja Treaty (Africa Trade Forum, June 2012). In November 2010, African ministers of trade met in Kigali recommending to accelerating the creating of a CFTA by 2017. In December 2011 in Accra at the $7^{\text {th }}$ Ordinary Session of AU Ministers of Trade Conference, the 2010 Kigali recommendation was re-affirmed. Subsequently, in January $201218^{\text {th }}$ Ordinary Session of the African Union Summit in Addis Ababa, African heads of state and government endorsed Accra's declaration on "Boosting Intra-Africa Trade and Establishment of a Continental Free Trade Area" on 2017 (Mevel and Karingi, 2012).

A joint initiative of UNECA, AUC and ADB called the African Trade Forum was designed as one of the supporting structures and building blocks for the establishment of the CFTA. This was in line with the AU Summit Declaration (Assembly/AU/Decl. 1 (XVIII) request to the AUC, UNECA, ADB and other relevant agencies to take appropriate measures including studies, technical supports to RECs and sensitization of member states and partners for the effective, implementation of the CFTA roadmap (Africa Trade Forum, 2012).

\section{THE ARCHITECTURE OF THE PROPOSED CONTINENTAL FREE TRADE AREA (CFTA) IN AFRICA}

The CFTA architecture comprises organs and mechanisms such as the High-Level African Trade Committee (HATC) at the apex; Conference of AU Ministers of Trade; the CFTA Negotiations Forum; the African Trade Forum, the African Business Council; the African Trade Observatory; Monitoring and Evaluation Mechanism; and Trade Dispute Settlement and CFTA Agreement Enforcement Mechanism. The HATC consists of some Heads of State and Government of the AU (the Chairs of RECs) whose main role or function is to serve as champions for fast-tracking the establishment of the CFTA and promotion of intra-African trade. The HATC was inaugurated during the $19^{\text {th }}$ Ordinary Session of the AU Summit held in Addis Ababa in July 2012. Many of these components or organs of the CFTA are to some extent innovative taken into account lessons from and drawbacks in Africa's experience with market integration and regional trade liberalisation programme (Africa Trade Forum, 2012). Just like the proposed Tripartite Free Trade Area (T-FTA), there shall be a continental task force headed by the AU Commission and Chief Executives of the RECs with responsibility for commissioning the necessary baseline studies and documents for establishing the CFTA and to drive the process (AUC \& UNECA, 2012). The two-stage approach is for other RECs to form a parallel arrangement similar to the proposed T-FTA prior to reaching the CFTA; while the one-stage approach is for RECs to join the CFTA directly. The AUC in conjunction with UNECA and ADB will be responsible for monitoring the development of FTAs within and between the RECs; provide guidance leadership, technical and political support to expedite the process of establishing regional and continental FTAs; provide information and evidence-based analysis through studies; mobilize the support of stakeholders for the realization of CFTA; provide a platform for the sharing of experiences among African FTAs. Whilst the AU member states shall be responsible for negotiating the respective FTAs in RECs and the CFTA. For example, the issues that are to be negotiated include rules of origin; tariff reduction schedules; removal and elimination of non-tariff barriers (NTBs); customs and transit procedures; and trade facilitation. Technical assistance will be provided by various donors and partners as appropriate (AUC \& UNECA, 2012).

The CFTA is meant to be driven by the AUC, RECs and member states with close involvement of all stakeholders such as private sector, civil society, etc. The underlying principles of CFTA include reciprocity; substantial liberalization; non-discriminatory principle; most favoured nation (MFN) treatment; flexibility, special and differential treatment. The substantial liberalization should be established on a tariff-free, quota-free and exemption free basis. Reciprocity in CFTA will entail that there are no free riders. The flexibility, special and differential treatment takes into account the special needs and concerns of weaker economies (AUC \& 
UNECA, 2012).The objectives of CFTA would be to provide the basis for establishing a Continental Customs Union (CCU) by 2019 and eventual African Common Market (ACM) through creating a single continental market for goods and services with movement of business persons and investments; expanding intra-African trade by dismantling tariff and non-tariff barriers; enhancing mutually advantageous commercial relations through trade liberalization schemes; unleashing the entrepreneurial dynamism and spirit across the continent; boosting intra-African trade through better harmonization and coordination of trade liberalization regimes or trade facilitation instruments across RECs; resolving the challenges of multiple and overlapping memberships; fast-tracking regional and continental integration in Africa; enhancing the competitiveness of the industries through exploiting the opportunities of large-scale production, continental market access and better allocation of resources; increasing the inflow of FDI; developing African industries to generate employment and reduce poverty; achieving sustainable economic growth; and strengthening of the integration of Africa into the global economy. These are geared towards achieving the much desired and long-awaited African Economic Community by 2025 (AUC \& UNECA, 2012; African Trade Forum, 2012; BUA News, 2012; Nkuepo, 2012a).

\section{A COMPENDIUM OF MAIN TRADE CONSTRAINTS IN AFRICA TODAY}

Intra-Africa trade has consistently remained low approximately averaging $10 \%$. Over $80 \%$ of imports and exports of African states are destines for markets outside the continent. Whilst intra-regional trade in other regions of the world such as EU is over 60\%, North America is 40\%, and Asia over 40\%, all much higher than in Africa. The efforts of RECs in Africa though substantial and laudable have had limited or marginal impact on intra-Africa trade. It has been noted that Africa does not trade with itself because of differences in trade regimes, restrictive customs procedures; administrative, bureaucratic and technical barriers; limited productive capacity; inadequate trade-related infrastructure, trade finance and trade information; lack of factor market integration; and inadequate focus on internal market issues (AUC \& UNECA, 2012). But it is pertinent to point out that generally, the share of Africa in the global trade in 2010 is very poor at about 4\% (Mevel and Karingi, 2012).

Africa is currently facing a number of trade-related challenges such as low share in world exports and low intraAfrican trade, poor trade infrastructure and supply-side constraints, lack of export diversification, and tariff and non-tariff barriers. The share of Africa's exports in total world exports is only about $4 \%$. Essentially, African exports are directed outside the continent. The structure of Africa's exports to the rest of the world reflects market concentration in primary product to just a few partners, the EU and the US, receiving $42.8 \%$ and $18.1 \%$, respectively in 2010. For example, oil exporting African countries like Angola, Gabon, Libya, Nigeria, etc. are among the least diversified African countries in terms of exports (Mevel and Karingi, 2012).

The average protection rate of Africa is $8.7 \%$, for example, Ethiopia imposes an average tariff of $13.3 \%$ on its imports coming from other African countries and faces an average tariff of $19.5 \%$ on its exports to the rest of Africa. This means that Ethiopia is on average more protectionist than the rest of Africa adopting on average a $4.6 \%$ point higher tariff on its imports from the continent. Only about one-third of African countries such as Burkina Faso, Comoros, Eritrea, Guinea, Guinea Bissau, Lesotho, Liberia, Malawi, Mali, Namibia, Senegal, Swaziland, Togo, Uganda, and Zambia, imposed and faced protections are on average lower than the relatively high averages for the continent. The rest of the African countries are, on average more protectionists than Africa. A quarter of African countries like Cameroon, Equatorial Guinea, Ethiopia, Ghana, Morocco, Mozambique, Seychelles, Tanzania and Tunisia, are on average more protectionists and face on average, more trade barriers than Africa (Mevel and Karingi, 2012). With average protection rates of $9.5 \%$ faced by African countries on their exports to non-African partners and $12.4 \%$ on Africa's exports to African countries, African countries face a higher protection rates from one another than from non-African countries. At the country level, TBs imposed are considerably different and extremely complex and heterogeneous. For example, Swaziland faces the highest average tariff when exporting its agricultural products to non-African countries at 96.7\%; Seychelles imposes the highest average tariff on agricultural products imported from Africa at 53.6\%. Yet the higher intra-African trade protection rate partly explains the low levels of intra-regional trade in Africa (Brenton and Isik, 2012).Several reasons account for low intra-African trade. The production and export structures of most African economies are geared towards primary products such as minerals, timber, coffee, cocoa, and other raw materials for which demand is externally oriented. Inadequate infrastructure remains one of the chief obstacles to intra-African trade and investment, and private sector development. This limits the range of products African countries can trade among themselves. In other words, intra-African trade is weak partly because fundament aspects of trade logistics such as infrastructures like transport, energy, ICT, etc. are compromised. Trade constraints such as poor infrastructure make trade physically difficult if not impossible no matter the trade regime (AUC \& UNECA, 2012). Therefore, apart from TBs, many NTBs limit African trade such as lengthy/custom procedures, sanitary and phytosanitary measures, product standards, anti-dumping measures, countervailing duties and licensing (Hummels, 2001; Mevel and Karaigi, 2012). The point being made is that TBs are not the sole constraints to trade in Africa. NTBs are usually more difficult to quantify. In other words, a major factor accounting for the low level of intra-African trade has been the numerous constraints 
associated with trade facilitation like complicated customs requirements and procedures; unfavourable domestic trade regulatory environment; poor transport and logistic service provision and infrastructure networks; physical barriers, harassment and corruption along trade and transit corridors; limited knowledge and understanding of trade facilitation instruments and measures by public sector officials, private sector operators and other trade constituents. Besides contributing to delays and loss of time in conducting business, these constraints impose high transaction costs for African traded goods and services thereby undermining their competitiveness in the international market (Mevel and Karingi, 2012; Africa Trade Forum, 2012).

Also, poorly developed financial markets and lack of widely available trade and investment finance for African businesses, have been a major hindrance in boosting trade in Africa. The paucity of credit and finance and insurance limits businesses' liquidity and undermines their ability to obtain production inputs. In general, it limits the potential for intra-African trade and constrains diversification efforts in Africa. Africa faces serious infrastructural bottlenecks thereby affecting the competitiveness of Africa's exports and contributing to significantly low volumes of intra-African trade. For example, transport costs in Africa are among the highest in the world and poor transport infrastructure is responsible for $40 \%$ of transport costs in coastal countries and $60 \%$ in landlocked countries in Africa. More so, many sub-Saharan African countries continue to experience crisis conditions in national energy supply posing the biggest infrastructural challenge or trade-related constraints in Africa (Africa Trade Forum, 2012). Furthermore, multiple membership has impeded economic integration in two ways. One, directly by generating inconsistencies and incompatibilities and inhibiting coordination and harmonization of activities like customs union, free trade, single market, monetary union and single/common currency. Two, indirectly, by forcing member countries to dissipate scarce human and financial resources in seeking to service different regional communities and implementing differing, contradicting and conflicting treaties. In addition, multiple membership have also bedevilled the long running and still incomplete negotiations between several disparate groups of member states and the EU over the establishment of regional Economic Partnership Agreements (EPAs) (Jakobeit, Hartzenberg and Charalambides, 2005; Othieno and Shinyekwa, 2011). Overlapping membership to different trade regimes and instruments risk trade deflection, and dealing with them posed legal and administrative challenges to member states (Disenyanai, 2009; Zizhou, 2009). Whilst, one major problem of subgroupings in the African regional economic communities is that it undermines the commitment and allegiance of those African states towards the regional bodies (Okeke and Aniche, 2012; Aniche, 2015).

\section{THE PROSPECTS OF PROPOSED CONTINENTAL FREE TRADE AREA (CFTA) IN AFRICA}

A CFTA that embraces all the 54 African Union (AU) member states endowed with human resources of a growing and youthful population of over a billion people, if it succeeds in dismantling all TBs and NTBs to intra-African trade will unlock the continent's immense development potentials, boost its trade performance and integration into the global trading system, and reduce the continent's current heavy dependence on aid for development. The CFTA if effectively implemented will contribute significantly to the achievement of an integrated prosperous and peaceful Africa, a key objective of the AU (Africa Trade Forum, 2012). This will make for deeper and better continental market integration. Also, the experience that will be gained in negotiating trade-related issues in the context of the CFTA will be useful to African states when similar issues confront them in international trade negotiations. Thus, it has been noted that achievement of a successful CFTA will involve the removal of tariffs, the establishment of common rules of origin, the harmonization and simplification of customs regulations and procedures, and the elimination of NTBs to intra-African trade. Therefore, the establishment of a CFTA will lead to a significant growth and sustainable development. For example, the creation of the COMESA FTA led to a six-fold increase in intra-COMESA trade between 2000 and 2010 (AUC \& UNECA, 2012).Among other expected specific benefits that will accrue to African states from the creation of CFTA include increased food security through reduction of the protection rate on trade in agricultural commodities among the African states; increased competitiveness of Africa's industrial products through harnessing the economies of scale of a large continental market of about one billion people; increased rate of diversification and transformation of Africa's economy and the continent's ability to supply its import needs from its own resources; better allocation of resources; improved competition and reduced price differentials among African countries; growth of intra-industry trade and the development of geographically based specialization in Africa; reduced vulnerability of Africa to external trade shocks; enhanced participation of Africa in global trade and reduced dependence of the continent on aid and external borrowing (AUC \& UNECA, 2012). Thus, the CFTA is expected to engender substantial and social gains in Africa. For instance, intra-African trade in agriculture faces a higher protection rate than non-agricultural sector. As such, the CFTA will enable Africa to maintain food security and boost trade in agricultural goods. There is optimism that CFTA will enable Africa tackle most of the trade constraints or obstacles to intra-African trade. For example, African leaders and other stakeholders are optimistic that increased trade through initiatives like the Grand T-FTA and 
other potential inter-RECs FTAs will quickly transform into a CFTA with enormous benefits. It will enlarge markets for goods and services; eliminate duplicative, multiple and overlapping memberships; enhance customs cooperation and broader trade facilitation, promote harmonisation and coordination of trade instruments; and broader relaxation of restrictions on movement of goods, services and persons. The collaboration and cooperation of RECs through the CFTA will further improve regional infrastructure and consolidate regional markets through improved interconnectivity in all forms of transport and communication as well as promote energy pooling to enhance Africa's competitiveness (AUC \& UNECA, 2012). The CFTA will help fast-track the realisation of the vision of 1991 Abuja Treaty of an African Common Market, and ultimately, the African Economic Community (AEC).

The recent experiences of the RECs FTA show that public revenue can actually increase with the removal or lowering of tariffs on intra-regional trade compensating for the loss of tariff revenue both for small and large economies. For example, following the accession of Rwanda to the COMESA FTA, its revenue increased as a result of VAT on imports from the region. There is also more sophistication in intra-African trade goods than what Africa exports to the rest of the world. Despite existing level of intra-African protection on non-agricultural products, these exports still constitute a significant share of each country export within Africa (AUC \& UNECA, 2012).

It has also been noted that trade flows would be significantly enhanced with the establishment of vast free trade areas in Africa or liberalisation of intra-African trade. The creation of a CFTA would stimulate African exports by $4 \%$ or $\$ 25.3$ billion. Specifically, it is in agriculture that African exports will rise the most with the adoption of CFTA reforms with $9.4 \%$ or $\$ 5$ billion compared to baseline scenario in 2022. Africa's exports would increase in agricultural sector, and exports of wheat, cereals, sugar, meat, raw milk, dairy products and other food commodities would be the most stimulated. Africa exports of industrial products would also increase with $4.7 \%$ or $\$ 21.1$ billion (Mevel and Karingi, 2012).FTA reforms would be net trade creative for Africa as trade diversion effects will be largely compensated by the creation of new trade flows. The increase in African exports within the continent would strongly offset reductions of African exports to non-African countries. The net trade creation effect for Africa would be recorded in agriculture and in the industrial sector. But the reduction in African exports of services directed outside the continent would be larger than the increase of exports in services within the African continent (Jean, Laborde and Martin, 2008; Mevel and Karingi, 2012). Establishment of FTAs among African economies could lead to substantial increase in trade flows within the continent, considering the high trade protection levels. But this will require adjustment costs such as tariff revenues losses. The benefits of CFTA could be considerably enhanced and offset related adjustment costs, if accompanied by other policies such as the reduction of NTBs. Agricultural commodities could reap important gains from such trade policies. The trade creating effect could lead to higher demand for imports from African states, and thus, to higher productions (Alcala and Ciccone, 2004; Mevel and Karingi, 2012).

With opening up of African economies, competition will increase on the continental level following the creation of CFTA. Trade flows will be reoriented just as African imports from African partners from within and outside the continent will be replaced by imports from African partners benefiting from better market access. With tariff cuts, this will lead to terms of trade reductions. African imports from non-African developing countries would decrease by $\$ 3.2$ billion or $1.6 \%$ with the formation of CFTA. While African imports from developed countries will decrease by $\$ 6.2$ billion or $1.7 \%$. In other words, the share of intra-African trade would be enhanced by $5.2 \%$ over a 12 -year period, rising from $10.3 \%$ in 2010 to $15.5 \%$ in 2022 . For agricultural goods, the share of intra-African trade would grow from $20 \%$ to $28.3 \%$ from 2010 to 2022 . With subsequent full removal of TBs, the initially large shares of African industrial and services exports to the rest of the world would be reduced, falling from $89 \%$ in 2010 to $83 \%$ in 2022 in industry and $97.7 \%$ in 2010 to 96.6 in 2022 in services (Minor and Tsigas, 2008; Mevel and Karingi, 2012). The increase in trade of industrial goods from the dominant trade-creating effects of the FTA reforms would increase intra-African trade by about half over a 12year period from $10.2 \%$ in 2010 to $15.5 \%$ in 2022 . While the eventual creation of a CFTA would increase the share of intra-African trade though not as expected or desired (Boumellsaa, Laborde and Mitaritonna, 2009; Mevel and Karingi, 2012). The formation of CFTA would amplify the gains from the establishment of RECs FTAs such as marginal increase in continental exports, real income, and real wages for all categories of workers. Agricultural exports would be significantly stimulated following the removal of relatively high initial TBs, and unskilled workers employed in agriculture would see their purchasing power enhanced (Decreux and Fontagne, 2009). Real wages for all categories of African workers would also be positively affected by the formation of large free trade areas. For instance, with the implementation of a CFTA unskilled workers employed in nonagricultural sectors would obtain the highest real wages increase of $0.8 \%$; while their unskilled counterparts engaged in the agricultural sector would see their income raised by $0.74 \%$ for the year 2022 . But to a lesser extent, skilled workers in the sector would also get positive real wage variations (Mevel and Karingi, 2012).With the effective implementation of a CFTA and reduction of NTBs, the share of intra-African trade will more than double rising from $10.2 \%$ in 2010 to $21.9 \%$ in 2022 . Also, the introduction of trade facilitation 
measures would expand the exchanges of industrial goods thereby increasing the sophistication of intra-African trade. The increase of Africa's industrial exports would surpass that of agricultural exports in relative terms leading to higher wage increase for skilled and unskilled workers employed in non-agricultural activities than for their counterparts in agriculture (Ben and Osakwe, 2006; Mevel and Karingi, 2012). More importantly, the proposed CFTA is expected to eliminate duplicative/multiple membership, proliferation of regional economic blocs, and sub-groupings. This is to say that the proposed CFTA has the prospect of removing or resolving the problem arising from the participation of member states in two or more regional economic communities, or even regional economic, political and security cooperation or architecture that may compete with or undermine one another. The proposed CFTA will, therefore, reduce combined memberships of RECs from 99 memberships to 53 or at most 54 memberships thereby eliminating 84 multiple memberships of African states in the eight pillars of AEC (Okeke and Aniche, 2012; Aniche, 2015).

Therefore, harmonising the trade arrangements through FTA could minimise and eventually eliminate the contradictions of overlapping memberships furthering the vision of a united Africa. This would mean that countries would not have to choose one trading bloc over another. It is important that second and subsequent phases of these negotiations be used as a vehicle towards greater convergence in interfacing regionally and with the third parties (Disenyanai, 2009; Zizhou, 2009; Aniche, 2015).

\section{THE CHALLENGES OF THE PROPOSED CONTINENTAL FREE TRADE AREA (CFTA) IN AFRICA}

The pessimists argue that the establishment of the CFTA in Africa will not automatically enable Africa to tackle the various trade constraints hampering intra-African trade as a result of the enormous challenges that will confront the proposed CFTA beyond trade constraints. Africa is still confronted with some major development challenges capable of hindering the proposed CFTA some of which include widespread poverty, marginalisation in global trade and limited capacity of its trade to serve as a key engine of sustainable socioeconomic development. For example, it has been noted that Africa accounts for about $4 \%$ of the global trade and its participation as exporter in manufactures and services is even much lower. At around 10\%, the level of Africa's intra-regional trade is the lowest among the major regions of the world rendering its economies highly vulnerable to trade shocks emanating from outside the continent; when $40 \%$ of North American trade is with other North American countries, and 63\% of trade by countries in Western Europe is with other Western European countries (Africa Trade Forum, 2012; AUC \& UNECA, 2012). Therefore, the opportunities and benefits of the CFTA will definitely come with significant challenges that most African countries might face in the process of opening up their national markets to the whole continent. The CFTA will be confronted with the problem arising from liberalization reforms. For example, as world prices of food products slightly increase, net-importing African countries like Angola, DRC, Mozambique, Botswana, North African countries, Nigeria and Central African countries are hurt as their real income reduced (Mevel and Karingi, 2012). It is still difficult to see how all economies within the FTAs will be transformed to a level of shared equal benefits from the proposed CFTA even in long-term (AUC \& UNECA, 2012). Many African scholars are sceptical about the CFTA initiative because the vast majority of African leaders are generally characterised by their passivity, slowness and tendency to depend on foreign aid. It is left to be seen how they will transform their political decision into action and effectively implement the initiative beyond rhetoric. Also, already there is slow progress towards FTAs due to inadequacy of institutional framework for realisation of important objectives; inadequate financing mechanism; multiplicity of inconvertible currencies; obstacles to factor mobility like labour, capital and enterprise; inadequate finance and credit guarantee; and lack of trade information system (Nkuepo, 2012b). Another major challenge for the proposed CFTA will be how to wind-up and phase-out the eight RECs which may lead one to suggest that the CFTA would co-exist with the existing RECs until such a time that all legal instruments have been dealt with so as not to create a vacuum. There has been also rhetoric of continental unity and regional integration which is not matched by practical action. There are also reasons to suspect that grand political pronouncements and agreements at the continental level may not be backed up by implementation and support at the national level (Disenyanai, 2009; Musonda, 2009; Woolfrey, 2012; Aniche, 2014).A strict removal of TBs will certainly not be sufficient for the fact that African economies are extremely heterogeneous. While the decision to establish the pan-African FTA is unambiguous, the scope of its issues coverage is not clear and remains to be decided. The T-FTA and REC FTAs are already behind schedule when meeting the target date of 2017 for CFTA depends on the successful conclusion of T-FTA and other RECs FTAs by 2014 and of the conclusion of the CFTA negotiations in 2016 requiring implementation of some activities. For instance, the RECs that will constitute the building blocks of the CFTA are at different stages in the development of their regional integration. While some such as the COMESA and EAC, have advanced beyond the level of an FTA; others like ECCAS and AMU, are yet to effectively attain FTA. There is thus every possibility that the process leading to the establishment of CFTA may not be concluded in 2017. Some countries and RECs may not even want to join the CFTA at that date. Not a few consequently consider 2017 to be 
unrealistic (Lunogelo and Mbilinyi, 2009; Africa Trade Forum, 2012). While at the regional level, the main challenge is ensuring the effective implementation of NTBs, there is a gap in terms of a continental trade framework that provides for inter-regional trade exchanges. For example, trade between countries that do not belong to the same regional economic community is either on the basis of a bilateral trade agreement or on a Most Favoured Nation (MFN) basis constituting to some extent a negative effect on the bilateral trade flows between countries across regions in Africa (AU \& UNECA, 2012). Thus, given the imbalances in the levels of developments in Africa, it would be a negligence to talk about boosting intra-African trade and creating a CFTA without ensuring equitable outcomes for member states through compensation mechanisms to address adjustment costs to greater trade opening or liberalization and help smaller or weaker countries build their production capacities (AU \& UNECA, 2012). Overlapping or multiple memberships to RECs continues to pose a big challenge towards negotiating and establishing a CFTA. For example, more than half of the African states totalling thirty one have dual membership of the eight RECs, while seven have multiple membership out which six belong to three of the eight RECs and one belong to four; only 15 or at most 16 African states maintain single membership and none belong to all the eight RECs. In addition, some of the RECs like Economic Community of Central African States (ECCAS), Economic Community of West African States (ECOWAS) and Southern African Development Community (SADC) contain within them sub-groupings. For instance, Economic and Monetary Community of Central Africa (CEMAC) is a sub-bloc of ECCAS; West African Economic and Monetary Union (UEMOA) and West African Monetary Zone (WAMZ) are sub-groups of ECOWAS; and South African Customs Union (SACU) is a sub-group of SADC. Consequently, some countries belong to customs union yet continue to negotiate towards establishing other customs union. Thus, it is yet to be clear how the proposed CFTA will remove the existing subgroups or the possibility of forming future ones (Okeke and Aniche, 2012; Aniche and Ukaegbu, 2014; Aniche, 2015). Also, commitment to integration varies across countries of Africa even as some countries have not undertaken any liberalisation within their respective RECs FTA. It will be difficult for them to commit to a CFTA when they cannot commit themselves to a smaller FTA. Some African countries remain sceptical of regional integration fearing domination by richer or more powerful states or ceding power or sovereignty to a supranational body. There is as well the challenge arising from trade negotiations, especially with some countries that are not in any form of FTA at the moment. Limited human resources, financial constraints and lack of other enabling capacities undermine the viability and sustainability of institutional arrangements at national, regional and continental levels. It is in doubt that Africa possesses the commensurate manpower and institutional capacities to handle the enormous challenges of implementing a CFTA when they cannot manage their affairs at the national level (AUC \& UNECA, 2012).

Moreso, it is uncertain how Africa can minister the huge financial outlay to provide the facilitating and complementary infrastructure because African countries are in general financially weak with incapacity to undertake such level of investments. Therefore, it will be confronted with the challenges of mobilizing the direct financial requirement to provide necessary trade-related infrastructure such as transport facilities like roads, airways, waterways, etc. information and communication (ICT), and for providing adequate human capacity, and for addressing compensation and adjustment costs arising from revenue and income losses due to the establishment of the CFTA. Furthermore, taking advantage of the regional differentiation for trade has been limited by weak productive capacities in Africa. As a result, the continued export of primary products like raw materials to external markets translate into export of jobs and by-products as well as potential for industrial development or the development of allied industries (AUC \& UNECA, 2012).

Low knowledge and understanding of trade facilitation instruments and measures by uniform personnel, law enforcement agents, drivers, etc., and limited access to information for the private sector on customs procedures for goods and vehicles in transit pose major challenges to the proposed CFTA. This is because the absence of market surveys and inadequate information on trade and market opportunities and customs formalities and procedures contribute to the high costs of doing business in the region. As a result many African businesses find it easily accessible and cheaper to trade with businesses outside of the region (AUC \& UNECA, 2012). The high dependence of African economies on customs revenue poses enormous challenge in RECs FTAs, and will be more so in the CFTA. This is because establishing any FTA or CFTA involves the reduction in TBs which may lead to loss of taxation revenue at least in the short-run that can cause difficulties for macro-economic management. Africa's smaller and less endowed economies may opt out of the CFTA because of the fear of losing revenue. It is important to state that the degree of impact of removal of TBs on tax revenue will vary in different countries depending on the share of customs revenues in the total public revenue (AUC \& UNECA, 2012). Tariffs may impede trade, but they also provide revenues for governments. In many African countries the receipts generated by enforcing tariff represent nearly $40 \%$ of the continent's total tax revenues in 2010 which is an important share of the government's income. More than three-quarters about $77.4 \%$ of tariff revenues come from tariffs imposed on non-African countries as Africa's imports mainly come from outside the continent. Consequently, most tariff-revenue-dependent African countries may be reluctant to pursue and implement the policy of CFTA (Boumellasa, Laborde and Mitaritonna, 2009; Nkuepo, 2012a; Mevel 
and Karingi, 2012). Although significant efforts have been made at the national and regional levels in addressing cost of doing business and other trade constraints in Africa, critical challenges still remain impeding progress in facilitating intra-African trade (Africa Trade Forum, 2012). For example, the World Bank Doing Business (2012) report indicates even as sub-Saharan Africa has significantly improved its reforms aiming to ease cross-border trading over the last few years; it still lags behind other regions. The study shows that it takes on average 31.5 days to export from a sub-Saharan African country and as much as 37.1 days to import to a subSaharan African country. In contrast it takes average of 10.5 days and 10.7 days to export and import from a high income OECD country, respectively (Mevel and Karingi, 2012). For instance, delays at African customs are on average longer than in the rest of the world such as 12 days in sub-Saharan African countries compared with seven days in Latin America, less than six days in Central and East Asia, and slightly more than four days in Central and East Europe. These delays add a tremendous cost to importers and exporters, and increase transaction costs of trading among African countries. The situation when crossing borders between African countries can be even worse. Also, delays and complicated procedures related to insuring goods and customs guarantee requirements raise the cost of exporting from Africa and compromise the competitiveness of the continent such that each day of delay reduces the export volume by about 1\% (AUC \& UNECA, 2012).

Consequently, African products lose its competitive cost structure when leaving the farm or factory gate due to custom delays. Thus, it is during the process of reaching the border where transport, storage and handling, and customs procedures raise the costs of exporting goods. Although measures including road transit facilitation instruments have been in place to promote free flow of goods, stakeholders including road transporters and shippers continue to face various difficulties along African trade and transit corridors. Some of these transport delays include roadblocks, unofficial fees, harassment and corruption along trade and transit corridors and at border crossings, different axle road limits, different vehicle standards and inspection requirements (AUC \& UNECA, 2012). The varying subsidisation of goods in different African countries is a great challenge to the formation of CFTA. This is antithetical to trade liberalisation encouraging cross-border smuggling in Africa. For example, petroleum products subsidies in Nigeria encourage petroleum products diversions and smuggling into other African countries where there are little or no subsidy on petroleum products. The same applies to subsidies in other sectors like agriculture and fertilizer, etc. To make matters worse there is a lack of harmonization and co-ordination of subsidies resulting in varying degree of subsidies in African states and total absence in others in the various sectors. Deficient telecommunication services tend to isolate African countries from one another. Consequently, it is much easier for business persons in Africa to deal with their counterparts in Europe and North Africa than with their fellow Africans because of difficulty of cross-border calls in Africa. Huge investments are still needed to physically integrate the continent and entire communities with effective transport, communication and other trade-related facilities to cut the cost of doing business in Africa (AUC \& UNECA, 2012). Many of the African countries have similar economic structures and thus produce, import and export similar products. Therefore, the scope of complementarities rather than competition in their trade relations is often very limited. This partially explains why they currently trade so little (usually less than 10\%) with each other (OxResearch Daily Brief Service, April 5, 2011). Therefore, the proposed CFTA will be unlikely to transform the vertical linkage and external dependence of economies of its members to a horizontal integration and interdependencies due to rentierism of most of its member states. For example, Mozambique's and Botswana's exports are oriented towards the EU in which mineral and metal products constitute 54\% of Mozambique's exports, while 71\% of Botswana's exports are primary products (Mevel and Karingi, 2012).

Ditto, with the intra-regional dependencies in which some of the economies of the prospective members will be dependent on South Africa, Egypt, Nigeria, etc. Two major implications flow from this; one, member states will be trading more with industrialised countries of the West, and two, the trade relations between many of the member states and the aforementioned regional hegemons will be skewed in favour of the latter. As a result, member states would be unwittingly aiding developed countries in undermining African free trade area. The point being made is that the proposed CFTA may not boost intra-regional trades as such, except in the case of trade between other member states and economic regional hegemons, because most of them are export-oriented primary producers whose primary products are in very little demand within the continent, and to remedy this will be very difficult (Ake, 1981; Nnoli, 1985; Aniche and Ukaegbu, 2014).As corollary to the above, the weak economic structure of most member states and the attendant economic crises, stagnation and instability of some of the member states will pose a great challenge to CFTA, and will continue to be a drawback to its prospects. It has even been stated that the proposed roadmap for regional integration may be unrealistically ambitions given the diversity of economies involved and the long term requirements (Disenyanai, 2009; Musonda, 2009).

The point is that challenges that have been met by the RECs individually may be magnified in the larger FTA if not dealt with effectively. Some of these challenges include economic polarization, fiscal challenges, negotiation with external parties, institutional weaknesses and political instability. For example, asymmetric product complementarities in the regions means that more developed economies of Egypt, Nigeria, South Africa, etc. are in much better position to market their exports raising a concern over possible economic 
polarization and disparity as investment may be attracted towards these economies that can undermine the proposed integration effort (Musonda, 2008; Disenyanai, 2009; Kalaba 2009). The less prepared countries are at risk of being swallowed economically by more powerful countries, as their local industries would suffer from the stiff trade competition from more rival firms in an open market. This competition may subsequently allow the more organised and developed economies to push weaker local firms out of business (Aniche, 2015).

The proposed CFTA would have to deal with the sub-national centrifugal tendencies like conflicts, crises, violence, ethnic nationalism, religious intolerance, terrorism, and ultimately civil wars. Political instability in some key member states including Somali, Sudan, the DRC, etc. renders the continent risky for investment, and counters the benefits of the envisaged CFTA (Disenyanai, 2009; Musonda, 2009). It suffices to say that the proposed CFTA will be situated in a crisis region where internal centrifugal forces of sub-nationalism and other forms of conflicts like xenophobia are ravaging the continent. It is obvious therefore that the internal centrifugal tendencies and wars between the proposed CFTA member states are the greatest challenge, the proposed CFTA would have to deal with, and it dwindles whatever prospects it has, and could indeed, pre-empt it (Aniche, 2014; Aniche and Ukaegbu, 2016).Also, the proposed CFTA would have to contend with several political differences which include the differences in the development ideologies of member states, and their fear of compromising their sovereignty or control over their territories (Ake, 1981). The import of this is that the proposed CFTA may be encumbered by conflicts or disputes between members like wars, armed conflicts, xenophobia, etc. Wars will in turn lead to the upsurge of refugees in the zone and worsen the economic crises in these countries (Aniche, 2015). This is exactly what Echezona (1998) is referring to when he avers that the intractable civil strife within the member states of ECOWAS and OAU (now AU) and the refugee crisis which they cause, are the constant reminders that the African states are too fragile to engage in the pursuit of regional integration or as he puts it: "of system wide community formation". The point being made is that numerous challenges awaiting the proposed CFTA are capable of overcoming its prospects or probably pre-empting its emergence.

\section{CONCLUSION AND SUGGESTIONS}

We began by arguing that chronologically, integration in Africa preceded European colonialism and as well predated European integration. But in the scramble for Africa, the continent was partitioned into specific spheres of influence in the Berlin Conference (1884-1885) among the various European powers. This partitioning has continued to haunt Africa many years after colonialism, reinforcing the fragmentation of African economies. The shadow of the Conference is still with us such that after over a century of panAfricanism and five decades of modern integration in Africa, African economies remain decimated.Subsequently, we noted that there are numerous constraints, threats and obstacles to intra-African trade; prospects, opportunities, and expected benefits of the proposed CFTA; and enormous challenges and problems confronting the proposed CFTA in Africa. Based on these trade constraints and other challenges, therefore, we conclude that numerous challenges awaiting the proposed CFTA are capable of overcoming its prospects or probably pre-empt its emergence.

In seeking for solution to the predicament of African integration, we insist that the solution should not be sought in the existing Euro-centric strategies or theories, but in a new theory; a post-neo-functionalism or post-neo-nationalism, as suitable for African situation and capable of solving its problems. Post-neofunctionalism advocates for people-centred or human-centric or bottom-up integration rather than top-down approach to integration, or state-centric or inter-governmental integration of neo-functionalism. Therefore, integration should be people-driven or private-sector-led rather than state-driven or public-sector-led. The role of the state should be regulatory or facilitative (Aniche, 2014).A number of recommendations flows from this (i) that African leaders should seriously commence with the task of national integration, nation-building and national development beyond rhetoric, and as such, as a strategy of eventually achieving regional integration in Africa (ii) as a corollary to the above, African leaders should desist from divisive politics of divide and rule or disintegrative nationalism; and work towards unleashing and synergising the collective energies of their people towards transforming the abundant and strategic mineral resources in their territories into manufactured goods necessary for diversifying their economies from the present rentierism needed for transforming their current dependency on the industrialised countries of the West and their neo-colonial influences into relations of interdependency, and (iii) set into motion a regional security organisation that will assist in addressing the national questions that result to civil wars or strife and help in resolving inter-state disputes, wars and other security challenges in the continent (Aniche, 2014).

\section{REFERENCES}

[1] Africa Trade Forum, June, 2012 - African Trade Policy Centre United Nations Economic Commission for Africa, Addis Ababa, Ethiopia: Can Africa Trade itself out of Poverty.

[2] Ake, C. (1981). A Political Economy of Africa. Ibadan: Longman Nigeria. 
[3] Alcala, F. and Ciccone, A. (2004). Trade and Productivity. The Quarterly Journal of Economics, 119 (2): 613-646.

[4] Aniche, E.T. (2014). Problematising Neo-functionalism in the Search for a New Theory of African Integration: The Case of the Proposed Tripartite Free Trade Area (T-FTA) in Africa. Developing Country Studies, 4 (20): 128-142.

[5] Aniche, E.T. (2015). The 'Calculus' of Integration or Differentiation in Africa: Post-neo-functionalism and the Future of African Regional Economic Communities (RECs). International Affairs and Global Strategy, 36: 41-52.

[6] Aniche, E.T. and Ukaegbu, V.E. (2014). Vertical Integration, Economic Dependence and African Regionalism: A Comparative Study of ECOWAS and SADC. ANSU Journal of Peace and Development Studies, 2 (1), 58-76.

[7] Aniche, E.T. and Ukaegbu, V.E. (2016). "Structural Dependence, Vertical Integration and Regional Economic Cooperation in Africa: A Study of Southern African Development Community". Africa Review, 8 (2): 108-119. DOI: 10.1080/09744053.2016.1186866.

[8] AUC \& UNECA (2012). Boosting Intra-African Trade Issues Affecting Intra-African Trade. A Proposed Action Plan for Boosting Intra-African Trade and Framework for the Fast-tracking of a Continental Free Trade Area, January 23-30.

[9] Background Paper on Fast-tracking the Establishment of the Continental Free Trade Area (CFTA), Africa Trade Forum, 2012.

[10] Ben, H.H. and Osakwe, P.N. (2006). Global Trade Models and Economic Policy Analyses: Relevance, Risks, and Repercussions for Africa. In ATPC Work in Progress, No. 47, Addis Ababa: United Nations Economic Commission for Africa.

[11] Boumellassa, H., Laborde, D. and Mitaritonna, C. (2009). A Picture of Tariff Protection across the World in 2004: MAcMap-HS6, Version 2, IFPRI Discussion Paper, No. 00903. Washington, D.C.: International Food Policy Research Institute.

[12] Brenton, P. and Isik, G. (2012). Introduction. In World Bank De-fragmenting Africa: Deepening Regional Trade Integration in Goods and Services, The World Bank Report.

[13] Bridges Africa (2012). African Union Aims for Continental Free Trade Area by 2017, Volume 1, Issue 1, May.

[14] BuaNews (2012). Africa Targets Free Trade Area by 2017, January 31.

[15] Coleman, J.S. (1958). Nigeria: Background to Nationalism. Berkeley: University of California Press.

[16] Decreux, Y. and Fontagne, L. (2009). Economic Impact of Potential Outcome of the DDA. In CEPII Working Paper, No. 2009-01, Paris: Centre d'Etudes Prospectives et d'Informations Internationales.

[17] Disenyanai, T. (2009). Towards an EAC, COMESA and SADC Free Trade Area: Issues and Challenges. South African Institute of International Affairs (SAIIA) October.

[18] Draft Framework, Road Map and Architecture for Fast-tracking the Continental Free Trade Area (CFTA).

[19] Echezona, N. (1998). International Politics in Post-Cold War Era. Awka: Meks Publishers.

[20] Gassama, M.I.S. (2013). African Union: A Veritable Progeny of Pan-Africanism. AU ECHO, Special Edition for the $20^{\text {th }}$ AU Summit, Issue 05, January 27.

[21] Gehring, T. (1996). Integrating Integration Theory: Neo-functionalism and International Regimes. Global Society, 10 (3): 225-253.

[22] Haas, E.B. (1975). The Obsolescence of Regional Integration Theory, Berkeley: University of California, Institute of International Studies, Research Series, No. 25, 1975.

[23] Haas, E.B. (1976). Turbulent Fields and the Theory of Regional Integration. International Organization, 30 (2): $173-212$.

[24] Haas, E.B. (2001). Does Constructivism Subsume Neo-functionalism? In T. Christiansen, K.E. Jørgensen and A. Wiener (eds.), The Social Construction of Europe, (pp. 22-31). London: Sage.

[25] Hoffmann, S. (1966). Obstinate or Obsolete? The Fate of the Nation-state and the Case of Western Europe. Daedalus, 95 (3): 862-915.

[26] Hummels, D. (2001). Time as a Trade Barrier, West Lafayette, IN: Purdue University.

[27] Jakobeit, C., Hartzenberg, T. and Charalambides, N. (2005) Overlapping Memberships in COMESA, ECA, SACU and SADC, Trade Policy Options for the Region and APA Negotiations, Eschborn: Deutsche Gesellschaft für Technische Zusammenarbeit.

[28] Jean, S., Laborde, D. and Martin, W. (2008). Choosing Sensitive Agricultural Products in Trade Negotiations. IFPRI Discussion Paper, No. 00788. 
[29] Kalaba, M. (2009). Liberalisation of SADC Trade towards 2012 and Beyond in Inside Southern African Trade. Southern African Global Competitiveness Hub, 15, 8-9, January.

[30] Kimenyi, M.S. and Karingi, S.N. (2012). Foresight Africa: Top Priorities for the Continent in 2012: Consolidating Africa's Regional Integration Efforts, Washington, D.C.: The Brookings Institution Africa Growth Initiative.

[31] Laursen, F. (2008). Theory and Practice of Regional Integration. Jean Monnet/Robert Schuman Paper Series, 8 (3): 1-22.

[32] Lunogelo, B. and Mbilinyi, A. (2009) Convergence of COMESA-SADC-EAC Regional Frameworks. A Paper Presented during the Annual Forum for Private, Public and Academic Partnership on Trade Policy and Negotiations, Economic and Social Research Foundation, Dar-es-Salaam, November.

[33] Mattli, W. (1999). The Logic of Regional Integration, Cambridge University Press.

[34] McGowan, L. (2007). Theorising European Integration: Revisiting Neofunctionalism and Testing its Suitability for Explaining the Development of EC Competition Policy? European Integration online Papers (EIoP), 11 (3): 1-17.

[35] Mevel, S. and Karingi, S. (2012). Deepening Regional Integration in Africa: A Computable General Equilibrium Assessment of the Establishment of a Continental Customs Union. A Selected Paper for Presentation at the 7th African Economic Conference Kigali, Rwanda, October 30 - November 2.

[36] Minor, P. and Tsigas, M. (2008). Impact of Better Trade Facilitation in Developing Countries: Analysis with a New GTAP Database for the Value of Time in Trade. Research Report Submitted to GTAP 11th Annual Conference, Helsinki, Finland.

[37] Mo Ibrahim Foundation (2014). Facts and Figures - Regional Integration: Uniting to Complete.

[38] Mongelli, F.P. (2008). European Economic and Monetary Integration, and the Optimum Currency Area Theory, European Commission.

[39] Musonda, M.J. (2009). The COMESA Customs Union: Challenges and Opportunities in Inside Southern African Trade. Southern Africa Global Competitiveness Hub, 15, 10-11, January.

[40] Niemann, A. and Schmitter, P. (2009). Neo-functionalism. In A. Wiener and T. Diez (eds.) Theories of European Integration, (pp. 45-66). Oxford: Oxford University Press.

[41] Nkuepo, H.J. (2012a). Completing the World Bank Report: De-Fragmenting Africa: Deepening Regional Trade Integration in Goods and Services, Commenting on the World Bank Report $15^{\text {th }}$ February.

[42] Nkuepo, H.J. (2012b). Africa's Continental Free Trade Area: A Closer Look at the 2012 African Union's Action Plan for Boosting Intra-African Trade, Washington, D.C.: George Washington University Law School \& University of Iowa School of Law.

[43] Nkuepo, H.J. (2013). Reducing the Non-tariff Obstacles to Intra-African Trade: A Developmental Strategy. Africa's Trade Law Newsletters, 3.

[44] Nnoli, O. (1985). External Constraints of Pan-African Economic Integration. In W.A. Ndongko (ed.) Economic Co-operation and Integration in Africa. pp. 125-152. Dakar: CODESRIA.

[45] Okeke, V.O.S. and Aniche, E.T. (2012). Economic Regionalism and Dependency in Africa: A Study of African Economic Community (AEC). Arabian Journal of Business and Management Review, 1 (11): 523.

[46] Othieno, L. and Shinyekwa, I. (2011). Prospects and Challenges in the Formation of the COMESA-EAC and SADC Tripartite Free Trade Area. Economic Policy Research Centre (EPRC) Research Series, No. 87.

[47] OxResearch Daily Brief Service (2011). Africa: Tripartite Free Trade Zone Depends on Politics, April 5.

[48] Schmitter, P.C. (1969). Three Neo-Functional Hypotheses about International Integration. International Organisation, 23 (2): 161-166.

[49] Schmitter, P.C. (1970). A Revised Theory of Regional Integration. International Organization, 24 (4): 836-868.

[50] Schmitter, P.C. (2003). Neo-neo-functionalism. In A. Wiener and T. Diez (eds.) European Integration Theory, Oxford: Oxford University Press.

[51] Sherwood, M. (2012). Pan-African Conferences, 1900-1953: What Did 'Pan-Africanism' Mean? The Journal of Pan African Studies, 4 (10): 106-126.

[52] Tranholm-Mikkelsen, J. (1991). Neo-functionalism: Obstinate or Obsolete? A Reappraisal in the Light of the New Dynamism of the EC. Millennium: Journal of International Studies, 20 (1): 1-22.

[53] UNECA (2009). Mainstreaming of Regional Integration into National Development Plans and Programmes. Issues Paper. 5th Meeting of the Intergovernmental Committee of Experts for Southern Africa, 23-25 June, Lusaka. 
[54] Warleigh, A. (2006). Theorising Regional Integration Comparatively: An Introduction. A Paper Presented to the European Consortium for Political Research (ECPR) Joint Sessions of Workshops, Nicosia, Cyprus on April 25-30.

[55] Woolfrey, S. (2012). Industrial Development in the Tripartite Free Trade Area. In Free Trade Area Towards a New African Integration Paradigm? Stellenbosch: TRALAC.

[56] Zizhou, F.B. (2009). Modalities and Scenarios for Establishing a Trilateral Free Trade Area. A Paper Presented at the Sixth Southern Africa Forum on Trade in South Africa, August 3-4. 